\title{
EFFECTS OF CEMENTATION ON HYDRAULIC CONDUCTIVITY AND ON MECHANICAL STRENGTH OF BINARY PACKING SYSTEMS ${ }^{1}$
}

\author{
Lucimar Arruda Viana ${ }^{2}$, Dario Cardoso de Lima $^{3 *}$, Liovando Marciano da Costa ${ }^{4}$, Claudio Henrique de \\ Carvalho Silva ${ }^{5}$, Paulo Sérgio de Almeida Barbosa ${ }^{5}$ and Weiner Gustavo Silva Costa ${ }^{6}$
}

\footnotetext{
${ }^{1}$ Received on 03.08.2016 accepted for publication on 02.12.2016.

${ }^{2}$ Universidade Federal de Viçosa, Mestrado em Engenharia Civil, Viçosa, MG - Brasil. E-mail: <lucimarvianna@hotmail.com>.

${ }^{3}$ Universidade Federal de Viçosa, Departamento de Engenharia Civil, Viçosa, MG - Brasil. E-mail: <declima@ufv.br> .

${ }^{4}$ Universidade Federal de Viçosa, Departamento de Solos, Viçosa, MG - Brasil. E-mail: <liovando.costa@ufv.br>.

${ }^{5}$ UniversidadeFederal de Viçosa, Departamento de Engenharia Civil, Viçosa, MG - Brasil.E-mail: <silvac@ufv.br>and<pbarbosa@ufv.br>.

${ }^{6}$ Universidade Federal do Recôncavo da Bahia, Centro de Ciências Exatas e Tecnológicas, Cruz das Almas, BA - Brasil. E-mail:<weiner.ufrb@gmail.com>.

*Corresponding author.
}

\begin{abstract}
This paper addresses the topic soil stabilization for forest roads applications and analyzes the influence of the hydrated lime in structuring the sand fraction of an artificial soil composed of the sand fractions of two natural soils, simulating natural process of cementation of sands and using binary packing systems. The study included the following topics: (i) characterization of the mechanical strength and hydraulic conductivity of binary systems of the artificial soil; and (ii) effect of hydrated lime in structuring binary packing systems of the artificial soil. Soil samples were submitted to chemical pre-treatment, to obtain clean sand fractions from the two sandy soils with particle diameters ranging from 0.053 to $2 \mathrm{~mm}$, following sieving and separation of them in twenty-two classes with maximum (D)/minimum (d) ratios varying from 5.7 to 13.4. Sequentially, binary packing specimens of the artificial soil were prepared and then stabilized with $2 \%$ of a commercial hydrated lime. Next, the specimens were submitted to permeability and quasi-static cone penetration tests, in order to determine their hydraulic conductivity and cone tip resistance. Based on the obtained results, it was concluded that: (i) in the artificial soil, an increase of $\mathrm{D} / \mathrm{d}$ ratio led to an increase of cone tip resistance and decrease of hydraulic conductivity; and (ii) cementation with hydrated lime reduced the hydraulic conductivity and increased the cone tip resistance.
\end{abstract}

Keywords: Sandy soils; Hydrated lime; Permeability and cone tip resistance.

\section{EFEITOS DA CIMENTAÇÃO NA CONDUTIVIDADE HIDRÁULICA E RESISTEN CIA MECÂNICA DE SISTEMAS DE EMPACOTAMENTO BINÁRIO}

\begin{abstract}
RESUMO - No presente artigo, aborda-se a técnica de estabilização dos solos para uso em estradas florestais, com a análise da influência da cal hidratada na estruturação da fração areia de um solo artificial composto pelas frações areia de dois solos naturais, de modo a simular um processo natural de formação de camadas arenosas no campo, empregando-se sistemas binários de empacotamento de partículas. A pesquisa abrangeu os seguintes tópicos: (i) caracterização da resistência mecânica e da condutividade hidráulica dos sistemas binários do solo artificial; e (ii) estudo da influência da cal hidratada na estruturação dos sistemas de empacotamentos binários do solo artificial. As amostras de solo foram submetidas a pré-tratamentos para obtenção da fração areia limpa e posterior peneiramento para separação em vinte e uma classes, entre os diâmetros de 0,053 e 2,000 $\mathrm{mm}$, e trabalhando-se com relações entre o diâmetro maior (D) e o diâmetro menor (d) na faixa de 5,7 a 13,4. Sequencialmente, foram preparados corpos de prova de empacotamentos binários do solo artificial e deste com a adição de $2 \%$ de uma cal hidratada comercial. Posteriormente, os corpos de prova foram submetidos aos ensaios de laboratório de permeabilidade, para determinação da condutividade hidráulica,
\end{abstract}


e de resistência à penetração empregando-se um cone penetrométrico quase-estático, para determinação da resistência de ponta. Com base nos resultados obtidos, concluiu-se que: (i) a condutividade hidráulica e a resistência à penetração dos empacotamentos binários do solo artificial apresentaram reduções à medida que se aumentou a relação $\mathrm{D} / \mathrm{d}$; e (ii) a cimentação por cal hidratada reduziu a permeabilidade e elevou a resistência à penetração dos empacotamentos binários do solo artificial.

Palavras-chave: Solos arenosos; Cal hidratada; Permeabilidade e resistência de ponta do cone.

\section{INTRODUCTION}

From the historical perspective, the road and transport sector acquired great importance within the forestry enterprise, since its costs affect significantly the end value of the wood. In this context, the development of new construction materials acquires strategic importance, in particular with respect to the soil stabilization technique using local soils for forest road construction. In this paper, it is addressed the effect of the addition of small content of hydrated lime in structuring sandy soil systems, which are often the subgrade of forest roads.

The geotechnical behavior of a soil, especially in terms of shear strength, compressibility, and hydraulic conductivity, depends on its void ratio, suggesting that variations induced in this parameter are responsible for changes in its engineering behavior in the face of external loading applications.

According to Cruz (1996), the presence of cementation between particles also interferes in the mechanical behavior of soils, especially as regards to mechanical resistance and compressibility, due to the cohesion gain.

Rotta (2005) considers that in natural sands, cementation may occur through different processes. In some cases, the cementation agent is deposited soon after sedimentation when the soil is at a small depth, commonly, for example, in hard sands deposited with calcium carbonate in saturated environment forming calcarenites; in others, cementation may occur, also at small depths, by the action of iron oxide as cementation agent, as in case of sandstone.

The effects caused by the cementation phenomena on the geotechnical behavior of granular soils have not been explicitly considered in geotechnical studies, as Dalla Riva (2010) points out. In contrast, in geotechnical applications and other fields of knowledge, the basic knowledge on compaction of sandy soils is still limited. From this perspective, it is interesting to analyze the physical behavior of relatively simple systems, which could help in the formation of a theoretical base for the understanding of most complex systems.

In the present article, the influence of the cementation agent hydrated lime on the structuring of the sand fraction of a sandy soil artificially prepared from sand fractions of two natural soils was analyzed, employing specimens produced in binary packing systems and based on analysis of the parameters cone tip resistance and hydraulic conductivity.

\section{MATERIALS AND METHODS}

\subsection{Materials}

In the present study, an artificial soil (AR) composed by the clean sand fraction of two natural soils, named João Pinheiro (soil JP) and Cachoeira da Prata (soil CP), presenting differentiated morphometric parameters was used. Description of soils and sample collection places are as follows: (i) Soil CP: It is a sandy soil composed by more coarse and angular particles. The sample was collected in a river sand dredging site located on the right side of highway MG 238, which connects the cities of Sete Lagoas to Cachoeira da Prata, in Minas Gerais State, Brazil, at geographical coordinates $19^{\circ} 29^{\prime} 59.06^{\prime \prime} \mathrm{S}$; $44^{\circ} 29^{\prime} 42.25^{\prime \prime} \mathrm{W}$; and (ii) Soil JP: It is also a sandy soil, but presenting finer and more rounded particles. The sample was collected in the B horizon of dystrophic Yellow Latosol, in a slope located on the right side of highway MG 181, between the cities of João Pinheiro and Brasilândia de Minas, in Minas Gerais state, Brazil, at geographical coordinates $17^{\circ} 25^{\prime} 48.65^{\prime \prime} \mathrm{S}$ and $46^{\circ} 04^{\prime} 37.27^{\prime \prime} \mathrm{W}$.

The grain size distribution of soils CP and JP are, as follows (Dalla Riva, 2010): (i) Soil CP: 3\% of clay (diameter smaller than $0.002 \mathrm{~mm}$ ), $4 \%$ of silt (diameter between 0.002 and $0,06 \mathrm{~mm}$ ) and $93 \%$ of sand (diameter between 0.06 and $2 \mathrm{~mm}$ ); (ii) Soil JP: $16 \%$ of clay, $4 \%$ of silt and $80 \%$ of sand. 
The cementation agent used was a type CH III hydrated lime, commercially named Supercal, in order to reproduce carbonation reactions with the sand fraction of soil AR, which reflects part of the formation processes of certain sandy deposits in the field.

\subsection{Methods}

After air drying, soil samples CP and JP were passed through the $2 \mathrm{~mm}$ opening sieve, to remove the gravel fraction. The sieved material was submitted to the following pretreatments: (i) Sample dispersion: It was carried out by a mechanical disperser, working for 16 $\mathrm{h}$, at $50 \mathrm{rpm}$, and by chemical dispersal using $0.5 \mathrm{~mol}$ L-1 NaOH and deionized water. At the end of the process, samples were washed in $0.053 \mathrm{~mm}$ sieve, to separate the sand from the silt and clay fractions; (ii) Removal of organic matter: Sodium hypochlorite was used, with $\mathrm{pH}$ adjusted to 9.5 , in a water bath at $50^{\circ} \mathrm{C}$ for $6 \mathrm{~h}$, followed by washing in running water in $0.053 \mathrm{~mm}$ opening sieve; and (iii) Removal of iron oxides: A dithionitecitrate solution was employed in a water bath at 75 ${ }^{\circ} \mathrm{C}$ for $1 \mathrm{~h}$, using three sequential extractions, followed by washing of sample in running water in the 0.053 mm opening sieve.

Certified sieves were used for separation of soil AR sand fraction in twenty-two size classes, with the diameters 2.000, 1.680, 1.141, 1.190, 1.000, 0.840, 0.710, $0.590,0.500,0.420,0.350,0.297,0.250,0.210,0.177,0.149$, $0.125,0.105,0.088,0.074,0.062$ and 0.053 . The 0.053 $\mathrm{mm}$ sieve was incorporated to the study, although it already includes the superior part of the silt fraction, according to the soil-particle size classification scale (ABNT, 1995).

Larger diameter (D) particles of the clean sand fraction of soil CP and smaller diameter (d) particles of the clean sand fraction of soil JP were employed in the preparation of soil AR binary packaging systems.

The binary packaging specimens of soil AR were produced based on real volume, defined as the particle mass to density ratio. The composition of mixtures was carried out in percentage terms of real volume, ranging from $0 \%$ to $100 \%$, with increases of $10 \%$ of larger diameter particles, and from $100 \%$ to $0 \%$, with $10 \%$ variations of smaller diameter particles. Maximum density was obtained for soil AR composed by $30 \%$ and $70 \%$ of smaller and larger diameter particles, respectively (Viana, 2013).
The specimens preparation was carried out according to the methodology described by Dalla Riva (2010), but employing a laboratory sieve shaker with the following characteristics: (i) electromagnetic vibrator at a constant frequency of $3600 \mathrm{rpm}$; (ii) control of vibration intensity; and (iii) electromechanical timer of 60 minutes.

The procedure consisted of the initial deposition of larger diameter particles in approximate quantities of $50 \mathrm{~mL}$ in an acrylic apparatus aided by a funnel, in order to avoid particles from falling at once. With the aid of a sieve shaker, controlled vibrations (3600 $\mathrm{rpm}$ ) and intensity frequency (rheostat at position 2) were produced, to allow that particles could vibrate around their axis and self-adjust, without dislocations that could produce total volume increases, achieving the densest possible configuration (less volume) inside the compaction mold. This procedure was repeated until all larger diameter particles were deposited in the acrylic apparatus. Next, smaller diameter particles were introduced into the apparatus, as previously described, allowing them to migrate through the specimen porous paths formed by the matrix of larger diameter particles, until the highest possible depth was reached inside the compaction mold and, consequently, producing the densest possible binary packing configuration.

Table 1 presents the classes used in the preparation of specimens of soil AR, in order to study the influence of the hydrated lime in the structure of binary packing systems, regarding the employed $\mathrm{D} / \mathrm{d}$ ratios and mean values.

In the determination of the hydraulic conductivity of specimens of soil AR, it was used specimens $6 \mathrm{~cm}$ in diameter and $10 \mathrm{~cm}$ in height which were tested in a system composed of a set of thirty permeameters working at constant head developed by Dalla Riva (2010). During the tests, it was adopted the following procedures: (i) verification of time spent in specimens percolation using triplicates readings at six pre-defined distances in the graduated test tube; and (ii) calculation of hydraulic conductivity (k) by Darcy's equation (Head, 1982). The results of hydraulic conductivity reflect the mean value of nine permeability tests.

In order to determinate the cone tip resistance, specimens were prepared in a system constituted by a base and two cylinders, both in acrylic, with $10 \mathrm{~cm}$ height and $6 \mathrm{~cm}$ internal diameter. Next, the specimens were submitted to quasi-static cone penetration tests 
Table 1 - Classes used in the preparation of specimens of soil AR.

Tabela 1 - Classes empregadas na preparação dos corpos de prova do solo AR.

\begin{tabular}{ccc}
\hline Ratio $(\mathrm{D} / \mathrm{d})$ & $\mathrm{D}(\mathrm{mm})$ & $\mathrm{d}(\mathrm{mm})$ \\
\cline { 2 - 3 } & $2.000-1.680-(1.840)$ & $0.350-0.297-(0.324)$ \\
\hline 5.7 & $2.000-1.680-(1.840)$ & $0.297-0.250-(0.274)$ \\
6.7 & $2.000-1.680-(1.840)$ & $0.250-0.210-(0.230)$ \\
8.0 & $2.000-1.680-(1.840)$ & $0.210-0.177-(0.194)$ \\
9.5 & $2.000-1.680-(1.840)$ & $0.177-0.149-(0.163)$ \\
11.3 & $2.000-1.680-(1.840)$ & $0.149-0.125-(0.137)$ \\
13.4 &
\end{tabular}

employing a system designed and implemented by Dalla Riva (2010), with the following characteristics: (i) hydraulic driving system with course of up to $60 \mathrm{~cm}$; (ii) variable capacity load cells $(20,50,100$ and 200 kgf), to be used according to the material to be tested; (iii) cone penetrometer with $6.2 \mathrm{~mm}$ diameter; (iv) data acquisition system; and (v) computer. During the test, it were adopted the following procedures: (i) calibration of the load cell using calibration weight kit; (ii) calibration of the cone penetration speed so that it was in the range $15 \pm 5 \mathrm{~mm} / \mathrm{min}$; (iii) conversion of the sign received by the data acquisition system $(\mathrm{mV})$ in force $(\mathrm{kgf})$ and calculation of the cone tip resistance $\left(\mathrm{kgf} / \mathrm{cm}^{2}\right)$.

The parameters hydraulic conductivity and cone tip resistance were also used to study the influence of addition of hydrated lime in binary packing specimens of soil AR.

The hydrated lime content of $2 \%$ in relation to dry soil mass was used to produce cementation systems that comply with what DNIT (2006) describes as improved-lime soil. The addition of hydrated lime to specimens occurred using a sieve shaker. Lime was deposited in small quantities so that it could migrate between the empty spaces and reach the highest possible depth inside the molding cylinder, and deposition was interrupted when lime reached the maximum cylinder level. After addition of hydrated lime, test specimens were saturated by capillarity, for $24 \mathrm{~h}$. To accelerate the cementation process, the test specimens were placed in a hermetically closed chamber $14 \mathrm{~cm}$ in height and $30 \mathrm{~cm}$ in internal diameter, which was then submitted to vacuum, followed by $\mathrm{CO}_{2}$ enrichment at the pressure of $100 \mathrm{kPa}$ during 7 days. Next, specimens were placed in an oven at 105 ${ }^{\circ} \mathrm{C}$ for $24 \mathrm{~h}$. Subsequently to the addition of the cementation agent to the specimens, permeability, and quasi-static cone penetration tests were performed.
Figures 1A, 1B, 1C, and 1D depict, respectively, the equipment used for the determination of the hydraulic conductivity, the equipment for the measurement of
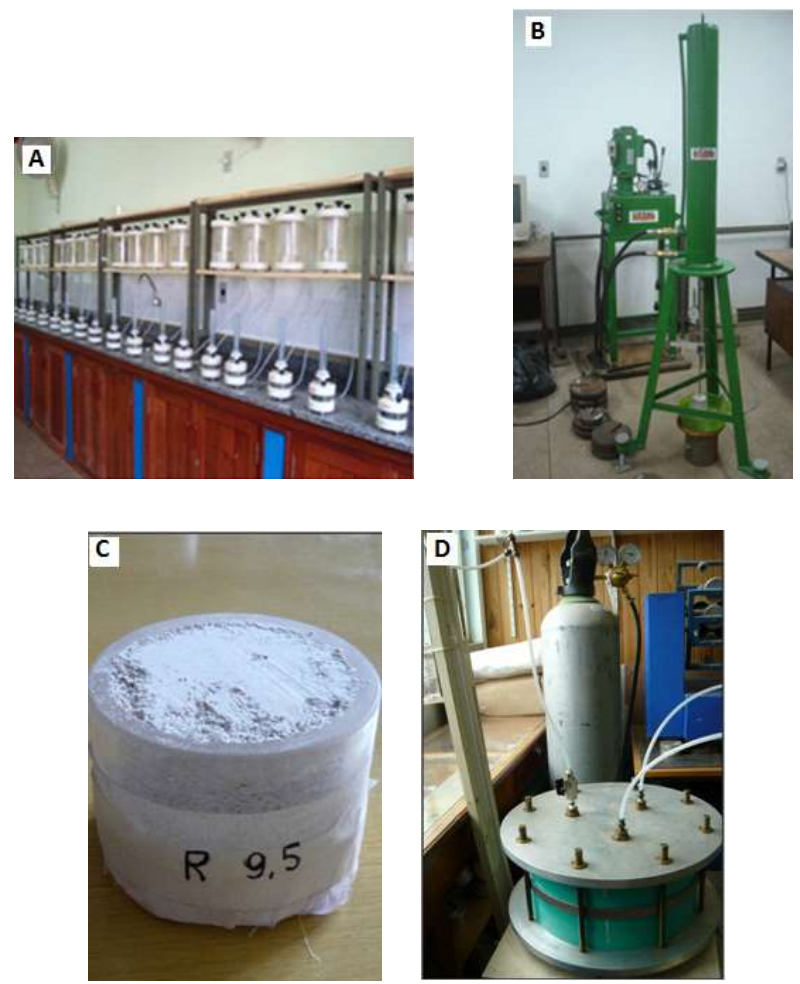

Figure 1 - The system used for running permeability tests under constant head (A), the quasi-static cone penetrometer system (B), the process of lime addition to the testing specimens $(\mathrm{C})$ and the hermetically closed chamber used for $\mathrm{CO}_{2}$ enrichment (D).

Figura 1 - Sistema utilizado para a realização dos ensaios de permeabilidade sob carga constante (A), sistema com base no cone penetrométrico quase-estático (B), processo de adição de cal aos corpos de prova $(C)$ e câmara fechada hermeticamente para enriquecimento com $\mathrm{CO}_{2}$. 
the cone tip resistance, the process of lime addition to the testing specimens and the hermetically closed chamber used for $\mathrm{CO}_{2}$ enrichment.

\section{RESULTS}

Figure 2 shows the curves of binary packaging of soil AR presenting the percentage of the particles of small diameters (d) in the soil versus the packaging density, for $\mathrm{D} / \mathrm{d}$ ratios ranging from 2.8 to 16 .

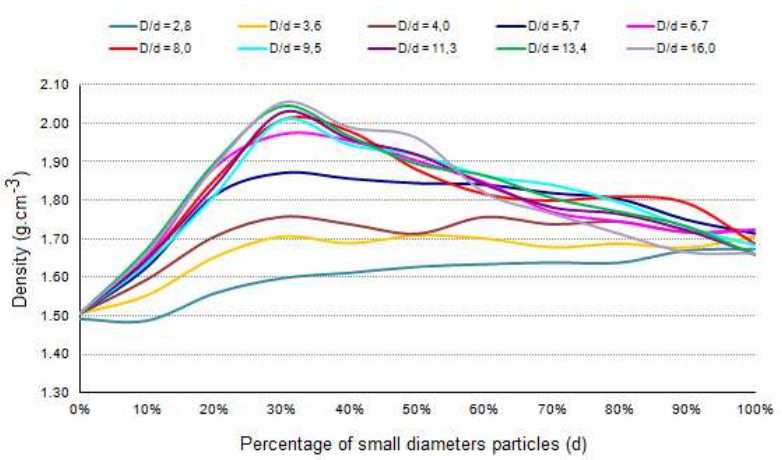

Figure 2 - Curves of binary packaging of soil AR: percentage of small particles versus density.

Figura 2-Curvas dos sistemas binários do solo AR: porcentagem de partículas menores versus densidade.
Table 2 summarizes the comparison of hydraulic conductivity testing data before and after addition of hydrated lime.

Table 3 brings out the comparison of cone tip resistance measured at the depth of $6 \mathrm{~cm}$ in the binary packing specimens of soil AR before and after addition of $2 \%$ lime.

\section{DISCUSSION}

From Figure 2, the maximum density occurred in a composition of approximately $30 \%$ smaller diameter particles (d), more clearly observed in $\mathrm{D} / \mathrm{d}$ ratios greater than 5.7. For ratios smaller than this value, the increase in packaging density was relatively low, leading to the conclusion that if the difference between the diameters of the particles involved is small, there is no significant elevation in packaging density. So, as it has increased the proportion of smaller grains (d) in the binary system, that have rounded shape and less roughness, its packaging density has increased significantly.

Data from Table 2 support that the increase of the $\mathrm{D} / \mathrm{d}$ ratio of binary packing systems produced the decrease of the hydraulic conductivity. As $\mathrm{D} / \mathrm{d}$ ratio

Table 2 - Comparison between the hydraulic conductivities of specimens of soil AR measured before and after addition of hydrated lime.

Tabela 2 - Comparação entre as condutividades hidráulicas dos corpos de prova do solo AR medidas antes e após a adição de cal.

\begin{tabular}{|c|c|c|c|}
\hline \multicolumn{4}{|c|}{ Hydraulic conductivity $-\mathrm{k}_{20}\left(\mathrm{x} 10^{-4} \mathrm{~cm} \cdot \mathrm{s}^{-1}\right)$} \\
\hline$\overline{\operatorname{Ratio}(\mathrm{D} / \mathrm{d})}$ & $\begin{array}{c}\text { Without } \\
\text { hydrated lime }\end{array}$ & $\begin{array}{l}\text { After cementation } \\
\text { with hydrated lime }\end{array}$ & $\begin{array}{c}\text { Percentage } \\
\text { Variation }\end{array}$ \\
\hline 5.7 & 58.80 & 25.58 & $56.50(-)$ \\
\hline 6.7 & 53.51 & 20.42 & $61.85(-)$ \\
\hline 8.0 & 44.30 & 16.46 & $62.84(-)$ \\
\hline 9.5 & 36.48 & 12.47 & $65.83(-)$ \\
\hline 11.3 & 31.71 & 9.36 & $70.48(-)$ \\
\hline 13.4 & 24.29 & 9.30 & $61.72(-)$ \\
\hline
\end{tabular}

Table 3 - Tip resistances of binary systems of soil AR determined before and after addition of hydrated lime. Tabela 3 - Resistências de ponta dos sistemas binários do solo AR determinadas antes e após a adição de cal.

\begin{tabular}{ccrr}
\hline \multicolumn{4}{c}{ Cone tip resistance $-\mathrm{R}_{\mathrm{P}}(\mathrm{kPa})$} \\
\hline Ratio (D/d) & Without hydrated lime & After cementation with hydrated limePercentage Variation \\
\hline 5.7 & 2920.00 & 8691.93 & $197.67(+)$ \\
6.7 & 2728.03 & 7400.03 & $171.26(+)$ \\
8.0 & 2458.24 & 7823.17 & $218.24(+)$ \\
9.5 & 2423.74 & 6299.30 & $159.90(+)$ \\
11.3 & 2180.75 & 6634.67 & $204.24(+)$ \\
13.4 & 2437.47 & 6376.63 & $161.61(+)$ \\
\hline
\end{tabular}


increased, the density of the system increased, resulting in lower void rate and, consequently, in the reduction of the hydraulic conductivity. Moreover, the higher the $\mathrm{D} / \mathrm{d}$ ratio, lower is the mean diameter of smaller particles (d) and, consequently, higher is its quantity in the packing, which elevates the superficial area of the system and causes higher resistance to flow. Another finding is that the binary systems under the action of hydrated lime showed lower hydraulic conductivity, with reductions ranging from $56.50 \%$ to $70.48 \%$. The water flow reduction can be associated with the fact that fine hydrated lime particles reduce the void rate and carried out cementation connections between particles in binary packing, for all studied $\mathrm{D} / \mathrm{d}$ ratios.

Comparatively, it is noticed that cementation with hydrated lime increased tip resistance, for all ratios (D/d). It is understood that tip resistance gains result from the filling of empty volume with hydrated lime and by cementation reactions produced by the interaction with $\mathrm{CO} 2$ in the air. This reaction transforms hydrated lime in a solid material similar to the original rock (limestone) used to manufacture this product. Furthermore, hydrated lime, for its agglomerate action, joins sand grains and with that reduces the incidence of relative movement between particles, making difficult the passage of the cone penetrometer. It is important to emphasize that the elevated values found for tip resistance may be also associated with the high $\mathrm{CO} 2$ concentration used in the production of carbonation reactions of the present study.

\section{CONCLUSIONS}

Data from this research support that hydraulic conductivity and cone tip resistance of binary packing systems of the soil AR: (i) decreased with increase in the $\mathrm{D} / \mathrm{d}$ ratio; and (ii) cementation with hydrated lime reduced the permeability and increased cone tip resistance.

\section{ACKNOWLEDGEMENTS}

The authors thank CAPES, CNPq (Grant No. 304171/ 2010-7) and FAPEMIG (Grant TEC PPM 00081-10) for supporting this research.

\section{REFERENCES}

Associação Brasileira de Normas Técnicas ABNT. NBR 6502: Solos e rochas. Rio de Janeiro: 1995. 18p.

Brasil. Ministério dos Transportes. Departamento Nacional de Infraestrutura de Transportes - DNIT. Manual de pavimentação. $2^{\mathrm{a}}$.ed. Rio de Janeiro: Instituto de Pesquisas Rodoviárias; 2006. 274p. (Publicação IPR-719)

Cruz PT. 100 Barragens brasileiras - Casos históricos, materiais de construção e projeto. São Paulo: Oficina de Textos; 1996. 647p.

Dalla Riva RD. Efeito das propriedades físicas dos grãos e agente de cimentação na estruturação da fração areia de solos arenosos [tese]. Viçosa, MG: Universidade Federal de Viçosa; 2010. 157p.

Head KH. Manual of soil laboratory testing: Permeability, shear strength and compressibility tests. New York: John Wiley \& Sons; 1982. v.2. p.335-747.

Rotta GV. Plastificação de um solo cimentado curado sob tensão [tese]. Porto Alegre: Universidade Federal do Rio Grande do Sul; 2005. 154p.

Viana LA. Efeitos da cimentação e da morfologia na condutividade hidráulica e na resistência mecânica de empacotamentos binários [dissertação]. Viçosa, MG: Universidade Federal de Viçosa; 2013. 109p. 